\title{
Reincarnating Storytelling Tradition: Medium for Inheriting Values and Strategies for Building Younger Generation Character
}

\author{
Arifuddin Arifuddin* \\ Faculty of Teacher Training and Education \\ Universitas Mataram \\ Mataram, Indonesia \\ arifuddin@unram.ac.id
}

\begin{abstract}
The majority of the members of the old generation have acquired psychological, cultural and mental benefits which could not be enjoyed anymore by the current generations. Such benefits result from the positive nurturant effect of the survival of storytelling tradition in the traditional communities practiced anytime and anywhere; namely, before going to bed, in the breaking moment in the rice field sides, even during the plantation in middle of the rice fields. It's lucky for the old generations, but unlucky for the younger generations. Today, storytelling has been an extinct tradition. These disadvantages get increased due to the high competition between parents and their children in social media activities. An important question, "How to reincarnate the storytelling tradition in the global and digital worlds?" Currently, traditional storytelling is difficult to witness anymore, documented folktales are limited, learning burden is high, and foreign folktales dominate. The extinction of the storytelling tradition should be anticipated by designing the strategies for reincarnating the storytelling tradition in attempt to inherit the moral values and build the young generations' character. The prospective strategies are discussed in this paper.
\end{abstract}

Keywords - reincarnate, storytelling, value, character, storytelling strategy.

\section{INTRODUCTION}

The past generations may have experienced psychological, sociological and cultural triumphs that are not necessarily enjoyed by the present generations. When the old generation, say those who are now in their 50s and older, tell stories and 'reminisce' about their past, both pleasant and 'sad' things (based on the current generation perspective), the current generation does not necessarily give a positive response, even responding, "It was in the past!" Unfortunately, they don't get information from the older generation about what interesting or 'high value' strategies for the inheritance of values, constancy in identity, and character building. What is that? One that is difficult for the present generation to enjoy is the storytelling tradition practiced by most of the ancient parents, not only before going to sleep, but also on other relaxing opportunities, for example, during breaks to grow rice fields or plant rice. It is suggested the storytelling be more effective when done at bedtime, during a relaxed atmosphere with family members, before or after lessons [1].

It's lucky for the older generation, in the past, the storytellers were still alive and actively did storytelling, and it is a shame for the current generation when most storytellers have passed away. The misfortune increases because all parties and generations are so busy, both parents and children are busy. Children are busy with social media and parents do not want to miss the social media use. Indonesia has a variety of folklores that can be used as tales' material for children. On one hand, the culture of reading stories to children is rarely done by parents, on the other hand, children's reading interest is still low, perhaps also interest in reading fairy tales (folklore). This poses a threat to literacy, including listening and reading skills.

The question, "What strategies are used for reincarnating the storytelling tradition in a modern world situation that is currently thought to be less supportive?" For example, the difficulty of finding storytellers, the limited number of recorded folklores, the burdens of learning that are getting heavier, and the onslaught of potentially threatening foreign tales. However, the growth and development of digital technology allows the reincarnation of the storytelling tradition through various media with a variety of strategies, both traditional and digital strategies, or non-formal and formal strategies.

In terms of benefits, except for an effort to maintain the existence of folklore (local tales), storytelling can be a vehicle for the young generations' character building. The moral values or noble characters such as, modelling, honesty, concern, honesty, concern, etc. are often found in local folklores. Younger generations should have good character. A reality that is difficult to dispute, there are smart children or parents, but not necessarily of good character (noble character).

Storytelling is a tradition that has deep roots in the life of Indonesian people in the past. It is likely to be able to bring back (reincarnate) the storytelling tradition. The storytelling tradition can be done through various channels, domains and strategies. Therefore, it is now time to design a storytelling strategy for reincarnating the storytelling tradition as a vehicle for inheriting the values and character building for the younger generations in particular.

\section{DISCUSSION}

\section{A. Character Building through Formal Education}

The Indonesian government has formulated the objectives of national education as stipulated in the Law Number 20 of 2003 concerning the National Education System. In Article 3, it is stated that "National education 
functions to develop capabilities and shape the dignified character and civilization of the nation in the context of educating the life of the nation, aiming to educate the life of the nation, developing the potential of learners to become people of faith and devotion to God Almighty, having good morality, healthy, knowledgeable, capable, creative, independent, and being democratic and responsible citizens. "Regarding character building, in general fairy tales contain positive values, morals and ethics [1], although there are some stories that contain stories or events that are not logical, for example, the figure of Malin Kundang who changed to a stone.

\section{B. Storytelling Tradion in the Past}

The past generations may have experienced psychological, sociological and cultural triumphs that are not necessarily enjoyed by the present generations. When the old generation, say those who are now in their 50s and older, tell stories and 'reminisce' about their past, both pleasant and 'sad' things (based on the current generation perspective), the current generation does not necessarily give a positive response, even responding, "It was in the past!" Unfortunately, they don't get information from the older generation about what interesting or 'high value' strategies for the inheritance of values, constancy in identity, and character building. What is that? One thing that is difficult for the present generation to enjoy is the tradition of storytelling practiced by most of the ancient parents, not only before going to sleep, but also on other relaxing opportunities, for example, during breaks to grow rice fields or plant rice.

It's lucky for the older generation, in the past, the storytellers were still alive and actively did storytelling, and it is a 'disaster' for the current generation when most storytellers have passed away. The misfortune increases because all communities and generations are so busy, both parents and children are busy. Children are busy with social media and parents do not want to miss the social media use anytime. Indeed, fairy tales are not always synonymous with listening to or reading stories or telling a story to children before bedtime. Storytelling is a suitable character-building medium for all ages, various professions, various places and opportunities. Fairy tales and messages simply need to be adjusted to the age and profession of the listener. If the listener is mature, storytellers usually tell wisdom stories that are conveyed by the storytelling method [2]. That is what parents did in the past, which is now very worth reincarnating.

\section{Importance of Parents' Role in Storytelling}

In the family environment, increasing children's interest in reading can be driven by parents. Many ways can be done by parents to foster their children's reading interest, one of which is by storytelling. Storytelling is an activity of listening to stories in a way that is fun and can stimulate a child's imagination and creativity. One way to encourage children to read is by storytelling. To start introducing fairy tales to children can be done anytime and anywhere. One of the best places to start storytelling is at home. When children and parents are at home, of course there are not many activities that can be done other than gathering with family, this opportunity can be used by parents to read or to tell stories to their children [3]. Below is a pictorial illustration.

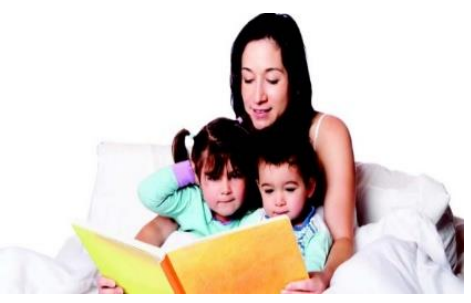

Fig. 1. parents to read or to tell stories to their children.

Children will focus on learning to read when they hear their parents' voices. By hearing their mothers' and fathers' voices, the children will feel calm, so as to be able to concentrate on reading books. Therefore, reading books that are appropriate to the children's ages and interest could be a surefire way to foster their interest in reading. With the growing enthusiasm of reading, it is expected that the children's knowledge atmosphere and inspiration widely broaden [4]. That is the important role of parents in interacting with children, and one of the ingredients is storytelling. In the family environment, reading culture must be taught early on. Reading can foster children's honesty and make them hold positive values.

\section{Benefits of Storytelling Habit and Reading Interest}

There is a premise, "Storytelling is an effective strategy in the immediate grades for furthering the development of speaking and listening skills, thus strengthening students' reading and writing [5]. In addition, research shows that storytelling increases story understanding [6]. Stories do not only function as academic entertainers, but rather as tools that facilitate understanding of the world around us, and see the relevance of concepts [7], [8]. In addition, storytelling can create enjoyable learning situations and help students remember relevant materials [9]. Indeed, storytelling contributes to increased literacy and interest in learning.

Educators ranging from kindergarten teachers to professors agree that storytelling helps increase understanding [10]. Besides, storytelling benefits teachers and students by forcing teachers to think critically of the teaching material they present. So, storytelling can increase literacy which can improve understanding and critical thinking skills (high order thinking) [11]. Storytelling or 'folktaling' is one of the best ways to increase children's interest in reading. This activity is also a very effective method of developing children's reasoning, curiosity and creativity and is an effective way to introduce books (reading materials) to children [1].

Until now, many storytelling activities have been abandoned by parents. Parents feel bothered and feel tired after a day of work, while in fact storytelling is a positive activity that can strengthen the relationship between mothers and children. A survey in the UK reported that almost $2 / 3$ of the children surveyed wanted their parents to take time to tell a story by bedtime, especially by the mother. The desires of the children are reasonable. Not a few benefits to storytelling for children, among others: 1) Helping psychological development and emotional intelligence of children, 2). Developing children's 
imagination; 3) Improving language skills, including politeness in language; 4) Increasing children's reading interest; 5) Building emotional and moral intelligence; 5) Forming children who are able to empathize. Many studies have proven the benefits of fairy tales for the psychological development of children [12].

Other various psychological benefits for children through telling folk tales:

- Fairy tales help children to imagine. Imagination is very important for the development of thinking power, creativity, communication skills and vocabulary mastery.

- Means to build ethics and values of life. Through the characters in fairy tales, our children can learn the values of honesty, humility, empathy, and a helping attitude. These are some aspects of affective skills developed in the 13 Curriculum.

- Stimulate children's interest in reading. After hearing a fairy tale, children are often interested in hearing another one and looking for a tale that has been recorded.

- Establish the closeness or proximity of parents and children. Storytelling agenda can be a means of gathering children and parents after their own busy working days. The storytelling is as an expression of affection and attention. Experts say that there is no standard age limit when storytelling should be started [13].

- Improve verbal skills.

- Develop reflective skills

- Improve the ability to think logically or critically.

- Improve listening skills.

Thus, storytelling potentially improves children' literacy and high order thinking. There are four benefits of storytelling, namely: 1) Fairy tales can sharpen the imagination and power of thought of children, and when dealing with fairy tales, children will visualize the story in accordance with their imagination; 2) Tales can strengthen the communication bond between storytellers and listeners; 3) Fairy tales are an effective medium for building various characters, values and ethics; 4) Fairy tales can help increase vocabulary [14]. In addition, there are six positive aspects of fairy tales, namely: 1) Developing imagination and providing deep emotional experiences; 2) Satisfying the need for self-expression; 3) Building moral education without having to patronize; 4) fostering a healthy sense of humor; 5) preparing literary appreciation; and 6) broadening children's imagination horizons [15].

In short, there are several benefits of storytelling for children, namely: developing imagination and emotional experience, satisfying the need for self-expression, becoming a vehicle for moral education, extending mental horizons and a sense of beauty, fostering a sense of humor, building a tradition of appreciating literary works, enriching vocabulary, strengthening social relationships, developing character and morals, fostering compassion, enhancing spirituality, fostering a fighting spirit, and strengthening communication ties.

Based on these notes, one of the benefits of storytelling is that it can increase children's reading interest. Consequently, storytelling should be 'reincarnated'. How come? Until recently, Indonesian children's reading interest is still low. Based on the study conducted by the United Nations Educational, Scientific and Cultural Organization (UNESCO), in 2012, the reading interest index in Indonesia only reached 0.001. It means that in every 1,000 people there is only one person who has an interest in reading. Regarding children's abilities, the data show that the ability of Indonesian children aged 15 years in the fields of mathematics, science, and reading compared to other children in the world is still low. The results of the 2012 Program for International Student Assessment (PISA), Indonesia ranked 64th out of the 65 countries that participated in the test [16]. Indonesian children's reading interest ranks $60^{\text {th }}$ out of the 61 countries surveyed [17]. UNDP also released that Indonesian adult literacy rates is only 65.5 percent, while Malaysia had reached 86.4 percent [1]

Puan Maharani, the Coordinating Minister for Human Development and Culture, in opening the 2018 National Coordination Meeting at the Jakarta National Library, Monday (3/26), confirmed that children's reading interest must be increased and fought for. Maharani admitted the lack of interest in reading communities in remote areas is due to the lack of books and other reading sources. Meanwhile, people who live in urban areas also have low reading interest because they are more interested in playing the internet [13].

The primary causes of low interest in reading are due to the difficulty in accessing children's books and the absence of initiating reading habits from their childhood. Parents need to provide special time to read books and accompany children to read, and be a good example and controller for children [4]. Therefore, the role of parents in enhancing reading habits is important to improve children's literacy skills [3]. As stated earlier, there are many factors which do not create reading habits, including the stronger influence of the internet as a medium of entertainment and social interaction media, with the disappearance of the tradition of storytelling and the lack of interest in reading, "How to build high literacy Indonesian generations?"

\section{E. Character of the Now State Genearations}

The worry about the symptoms of the decline of the nation's generation character is one of the triggers for the implementation of the 2013 Curriculum in Indonesia. Currently, the violation of rules, norms and values seems to be a culture. The simplest example, breaking traffic rules. I often see someone who physically looks noble character, but does not wear a helmet and ignoring the red light. Another example, bribery. I often hear rumors about the practice of bribery carried out between unscrupulous members of the legislative candidates and voters just before the election. This is a statement of an author in an Islamic bulletin. 'Bad behavior of some legislative candidates prior to this election is giving bribes to citizens to be willing to vote on them. While, in fact, they are actually not eligible for being people's representatives. If 
eligible or competent, of course they do not need to bribe, but prove that they are indeed worthy of being the people's representatives. Some people also ask us about this bribe money, may it be used? Based on the rumor, some of them will be given 20 thousand rupiah if they want to sign on a piece of paper which contains a promise that they will vote on the candidates in next the election. There are also those who carry out dawn attacks, give money early in the morning just before the voting' [18]. This quote indicates the courage to bribe in some members of the community. An indication of the character decline.

Some state officials, such as regents or mayors, have been and are being processed by the KPK (corruption elimination commission) and the court on suspicion of bribery or gratification. An example is the Regent in Kalimantan $\mathrm{R}$ who was charged with receiving gratuities of Rp. 469 Billion [19], and subsequently sentenced to 10 years in prison and a fine of Rp. 600 million by the Corruption Court judge for being proven to receive gratification of $\mathrm{Rp} 110,720,440,000$ from partners in the district government. The judge also revoked the regent's political rights for 5 years after completing her sentence. Not to mention the height of rumors about the habit of looking for loopholes to bribe at the time of receipt of CPNS. For example, there were 2014 CPNS bribes of Rp. 1, 99 billion, and 4 people became suspects [20]. It was also a teacher who reportedly violated immorality and even did sexual harassment to three 'santries' (religious school students) [21]. What is very inhumane is that there is news on television recently that shows an individual member of the Municipality legislation office, a Head of the City Education Office and a certain project contractor who were caught red-handedly committing a corruption of school rehabilitation funds due to an earthquake in a particular city written with headline 'Kejari Mtrm OTT Member of DPRD, Head of Education Corruption, Earthquake Rehabilitation Fund [22].

Moral and character decline in the world of education and social community is also possible. For example, when accepting new students, there was a very educated neighbor of mine who was brave and not ashamed of impoverishing himself, that is, making a poor certificate and faking an address, so that he could put his child in a 'favored' school with a certain zone. This is an example of educating children with lies and the habit of 'counterfeiting'. It's a place to put the information here.

It is possible that the perpetrators of such dishonorable actions do not learn from moral values in fairy tales. Imagine, in plain view, the tradition of storytelling is hard to find. The waning tradition of storytelling is compounded by the limited number of storytelling practitioners. Not everyone is trained in storytelling. Not everyone has the memory and skills to tell (verbally) events coherently and interestingly. Not everyone is skilled at storytelling. It is stated that storytelling is not a lecture. The lack of written culture in Indonesia, he said, was also due to the more popular speech culture or oral tradition. As a result, storytelling will not die. However, sometimes many young storytellers' talents break up in their teens. The reason is that school, middle or high school, cannot always facilitate maintaining storytelling traditions [17].
Related to literacy, fairy tales are the best media for teaching language and literacy. Fairy tales contain explorative and imaginative language expressions, which allow children to think, reflect on themselves and ask themselves for their existence because they present the beauty and contemplation of life. Fairytale is a medium for character building. Although there is still a need for a more comprehensive study, fairy tales include literary works that are able to build children's characteristics from an early age, one effective way to develop cognitive or knowledge aspects, affective or feeling, social and conative aspects [1]. Very many positive effects of storytelling for people.

It is expected that by accustomed to hearing fairy tales, children have the following characters: 1) Trustworthiness: trustworthy; 2) Respect: Respect: manners; 3) Responsibility: Responsible; 4) Fairness: being fair and wise in decision making; 5) Caring: shows concern for others, likes to help; 6) Citizenship: shows nationalism, love for the state / institution, loyal, disciplined to obey the rules; 7) Honestly: having an honest, open and honest attitude; 8) Courage: having a brave or challenging attitude; 9) Diligence: having a diligent, tenacious, never give up attitude; 10) Integrity: having integrity or consistent actions.

Reincarnating storytelling tradition can be done through the following strategies:

\section{1) Utilization of Digital Media}

Today is not always present with all negativity. Behind the loss of the tradition of storytelling through 'oral traditions' between parents and children, today many applications in various digital media that contain digital tales with interesting illustrations and artistic. Lifting folklore to the big screen or electronic media, such as radio and television, is also one of the strategies for reincarnating the storytelling tradition. In today's mobile and digital world, a child can easily hear or watch film stories anytime, anywhere. Moreover, there is a Video Call application. Children can interact with parents through 'listening' fairy tales that are read or told by their parents who are in other places.

\section{2) Formal Education Pathway}

Based on several views, theories and findings that have been presented previously, reincarnating the tradition of storytelling should be carried out through the following strategies: 1) Positioning folklore as a compulsory reading in the literacy programs; 2) Making folklore (local) as the main material in learning the narrative genre; 3) Assigning students to practice storytelling in class; 4) Encouraging teachers to love folklore; 5) Improving teachers' ability and skills in storytelling. Very many 'tips' or storytelling techniques written in various sources; 6) Holding storytelling contests for students; 7) Organizing fairytale or folklore writing competitions for students; 8) In the school library a fair amount of fairy tales are provided; and 9) What else?

\section{3) Non-formal Domains (Household and Social)}

- It is wise for parents to introduce the following sources of stories to children: Picture books, collections of myths, legends, animal stories, folklore (fables), autobiographies, textbooks, 
newspapers, children's magazines, stories family, history, interviews, photo albums, videos, films, television shows, games and so on. By introducing these reading sources, it is expected that children begin to be interested in reading.

- Parents should provide time for their children to tell stories, especially before going to bed. The implication is that the child's bedroom should not be separated or not too far from the children's bedroom.

- If possible, stories should be told using the local languages. Many traditional terms or expressions are difficult to translate or find in Indonesian language.

- Return to the village often and during the holidays, try to give the opportunity for children to listen fairy tales from family, for example their grandmother, in the village.

- Usually, in the village there are many places of recitation. After finishing the Al-Qur'an, it would be interesting if enriched with storytelling activities, especially by the teachers or other fairytale tellers.

- Prepare the ability to tell stories, especially prospective female brides. During the New Order era, prospective brides were obliged to memorize Pancasila. In Kabupaten Bima there was a regulation that a candidate bride must read or memorize certain letters (in the Qur'an).

- Local radio or television should show 'storytelling' programs.

- National storytelling contest needs to be held.

- Document fairy tales before storytellers die. This is important as the basis for the 'patents' if indeed these tales are truly unique to the local community. Do not let the motto emigration occur, as happened in the motto 'nggahi rawi pahu' in the district of Bima.

- Design Industry 4.0-based storytelling digital media.

\section{4) Scientific Study or Activity}

To find a strategy to reincarnate the storytelling tradition, it is necessary to conduct relevant studies or scientific activities. The following are some of the topics of study or scientific activities which potentially provide information or findings on strategies for reincarnating the storytelling traditions, namely: 1) An inventory of local tales; 2) Fables favored by children; 3) Study of values in fairy tales; 4) The use of language according to the age or level of education of the child; 5) The effectiveness of storytelling in children's moral/character education and education; 6) Seminars on fairy tales; 7) Contest of scientific work on fairy tales; 8) The application Digital media technology for joyfull storytelling; and 8) What else?

\section{CONCLUSION}

The extinction of the storytelling tradition in the community has narrowed down the opportunity to inherit the noble values to the younger generation. A variety of views, theories, and studies show that the storytelling tradition is definitely likely to make a positive contribution to the improvement of reading interest, intellectuality, social relations, fulfillment of psychological needs, entertainment, learning media, inheritance of the noble and moral values, and as media and strategies for building the character of the nation's generation. Therefore, reincarnating the lost tradition of storytelling should be done through the following media and/or strategies: 1) Utilization of Digital Media and 2) Formal Education Pathway.

\section{REFERENCES}

[1] I. K. Artana, "ANAK, MINAT BACA, DAN MENDONGENG," Acarya Pustaka, vol. 3, no. 1, pp. 26-36, 2017.

[2] D. Murdaningsih, "Didik Karakter Lewat Dongeng," 2014. https://www.republika.co.id/berita/koran/pendidikankoran/14/10/31/neau8a13-didik-karakter-lewat-dongeng (accessed Jun. 27, 2019).

[3] Fitri Risalatul, "Tumbuhkan Minat Baca Anak Melalui Dongeng," http://tribunnews.com/tribunners/2018/06/01/tumbuhkanminat-baca-anak-melalui-dongeng (accessed Jun. 28, 2019).

[4] C. C. Amiranti, "Minat Baca Anak Rendah, Perlu Terobosan Baru?," 2017. https://edukasi.kompas.com/read/2017/06/22/17223781/minat. baca.anak.rendah.perlu.terobosan.baru (accessed Jun. 18, 2010).

[5] R. E. McCarthy, "Student storytelling: A strategy for developing oral literacy in the intermediate grades," 1995.

[6] R. M. Powell and O. Murray, "Using Storytelling Strategies to Improve Student Comprehension in Online Classes.," J. Eff. Teach., vol. 12, no. 1, pp. 46-52, 2012.

[7] C. Coulter, C. Michael, and L. Poynor, "Storytelling as pedagogy: An unexpected outcome of narrative inquiry," Curric. Inq., vol. 37, no. 2, pp. 103-122, 2007.

[8] T. Sanchez, "The story of the Boston massacre: A storytelling opportunity for character education," Soc. Stud., vol. 96, no. 6, pp. 265-269, 2005.

[9] J. K. Frisch and G. Saunders, "Using stories in an introductory college biology course," J. Biol. Educ., vol. 42, no. 4, pp. 164$169,2008$.

[10] R. A. Bonney, "Teaching anthropology through folklore," Anthropol. Educ. Q., pp. 265-270, 1985.

[11] L. Caruthers, "USING STORYTELLING TO INTERRUPT A PARADIGM OF SAMENESS IN SCHOOLS.,"J. Ethnogr. Qual. Res., vol. 2, no. 3, 2008.

[12] Dini, "Manfaat Dongeng untuk Anak," 2012, [Online]. Available:

https://lifestyle.kompas.com/read/2012/05/15/14183692/manfa at.dongeng.untuk.anak.

[13] Priska Sari Pratiwi, "Minat Baca Masyarakat Indonesia Masih Rendah,” 2018. https://www.cnnindonesia.com/gayahidup/20180326160959-282-285982/minat-baca-masyarakatindonesia-masih-rendah (accessed Jun. 28, 2020)

[14] J. Zipes, Creative storytelling: Building community/changing lives. Routledge, 2013.

[15] D. S. Agus, Mendongeng Bareng Kak Agus DS, Yuk... Kanisius, 2008.

[16] Latief, "Kapan 'Story Telling' Itu Menyenangkan?," 2011. https://edukasi.kompas.com/read/2011/05/14/17515162/Kapan .Story.Telling.itu.Menyenangkan (accessed Jun. 28, 2019).

[17] Yudha Manggala P Putra, "Minat Baca di Indonesia Disebut Masih Rendah," 2018. https://republika.co.id/berita/pendidikan/eduaction/18/02/20/p4 gflk284-minat-baca-di-indonesia-disebut-masih-rendah (accessed Jun. 28, 2019). 
[18] M. A. Tuasikal, "Sogok Warga Agar Dapat Suara dalam Pemilu," 2014. https://muslim.or.id/20622-sogok-warga-agardapat-suara-dalam-pemilu.html (accessed Jun. 28, 2018).

[19] A. Gabrillin, "Bupati Kukar Rita Widyasari Didakwa Terima Gratifikasi Rp 469 Miliar,” 2018. https://nasional.kompas.com/read/2018/02/21/14025391/bupati -kukar-rita-widyasari-didakwa-terima-gratifikasi-rp-469-miliar (accessed Jun. 28, 2019).

[20] Edward Panggabean, "Suap CPNS 2014 Rp 1,99 Miliar, 4 Orang Jadi Tersangka," 2014. https://www.liputan6.com/news/read/2119902/suap-cpns-

2014-rp-199-miliar-4-orang-jadi-tersangka (accessed Jun. 28, 2019).

[21] Hadi Maulana, "Oknum Guru Agama Cabuli Tiga Santrinya, Gunakan Modus Jadi Pacar," 2018. https://regional.kompas.com/read/2018/06/05/06000061/oknu m-guru-agama-cabuli-tiga-santrinya-gunakan-modus-jadipacar (accessed Jun. 28, 2019).

[22] Martin, "Kejari Mataram OTT Anggota DPRD, Kadis Pendidikan yang Korupsi Dana Rehabilitasi Gempa," 2018. Kejari Mataram OTT Anggota DPRD, Kadis Pendidikan yang Korupsi Dana Rehabilitasi Gempa (accessed Jun. 28, 2019). 